\title{
Clinical pathway intervention compliance and effectiveness when used in the treatment of patients with severe sepsis and septic shock at an Intensive Care Unit in Spain
}

\author{
Ana Laguna-Pérez ${ }^{1}$ \\ Elisa Chilet-Rosell ${ }^{2}$ \\ Miguel Delgado Lacosta ${ }^{3}$ \\ Carlos Alvarez-Dardet ${ }^{4}$ \\ Joaquín Uris Selles ${ }^{5}$ \\ Carmen Luz Muñoz-Mendoza ${ }^{6}$
}

\begin{abstract}
The purpose of this quasi-experimental study was to assess levels of compliance with the intervention bundles contained in a clinical pathway used in the treatment of patients with severe sepsis and septic shock, and to analyze the pathway's impact on survival and duration of hospital stays. We used data on 125 patients in an Intensive Care Unit, divided into a control group $(\mathrm{N}=84)$ and an intervention group $(\mathrm{N}=41)$. Levels of compliance increased from $13.1 \%$ to $29.3 \%$ in 5 resuscitation bundle interventions and from $14.3 \%$ to $22 \%$ in 3 monitoring bundle interventions. In-hospital mortality at 28 days decreased by $11.2 \%$ and the duration of hospital stay was reduced by 5 days. Although compliance was low, the intervention enhanced adherence to the instructions given in the clinical pathway and we observed a decline in mortality at 28 days and shorter hospital stays.
\end{abstract}

Descriptors: Effectiveness; Critical Pathways; Sepsis; Critical Care.

\footnotetext{
${ }^{1}$ PhD, Full Professor, Departamento de Enfermería, Facultad de Ciencias de la Salud, Universidad de Alicante, Spain.

2 PhD, Scholarship holder, Facultad de Ciencias de la Salud, Universidad de Alicante, Spain.

3 Physician, Specialist in Critical Care Medicine, Unidad de Cuidados Intensivos, Hospital General Universitario de Alicante, Spain.

${ }^{4} \mathrm{PhD}$, Full Professor, Centro de Investigación Biomédica en Red en Epidemiología y Salud Pública, Universidad de Alicante, Spain.

${ }^{5}$ PhD, Associate Professor, Departamento de Enfermería Comunitaria, Medicina Preventiva y Salud Pública e Historia de la Ciencia Facultad de Ciencias de la Salud, Universidad de Alicante, Spain.

${ }^{6} \mathrm{PhD}$, Assistant Professor, Departamento de Enfermería, Facultad de Ciencias de la Salud, Universidad de Alicante, Spain.
} 


\title{
Observância e efetividade das intervenções de um protocolo clínico utilizado para pacientes com sepse grave e choque séptico de uma Unidade de Cuidados Intensivos da Espanha
}

O objetivo deste estudo quase-experimental foi avaliar o grau de cumprimento das intervenções de um pacote de medidas, em um protocolo clínico proposto para pacientes com sepse grave e choque séptico, e analisar o seu impacto na sobrevivência e duração das permanências hospitalares. Foram incluídos 125 pacientes, alocados no grupo controle $(n=84)$ e intervenção $(n=41)$ de uma Unidade de Cuidados Intensivos, na Espanha. 0 nível de adesão aumentou em pelo menos 5 intervenções do pacote de reanimação (de 13,1 para $29,3 \%$ ) e em pelo menos 3 intervenções do pacote de acompanhamento (de 14,3 para 22\%). A mortalidade hospitalar aos 28 dias diminuiu em 11,2\% e a duração da permanência hospitalar foi reduzida em 5 dias. Embora o cumprimento tenha sido baixo, a intervenção aumentou a adesão às indicações do protocolo clínico e foram observadas queda da mortalidade aos 28 dias e menor duração da permanência hospitalar.

Descritores: Efetividade; Protocolo Clínico; Sepse; Cuidados Críticos.

\section{Cumplimiento y efectividad de las intervenciones de un protocolo clínico utilizado en pacientes con sepsis grave y shock séptico en una Unidad de Cuidados Intensivos en España}

\begin{abstract}
El objetivo de este estudio cuasiexperimental fue valorar el nivel de cumplimiento de las intervenciones de los paquetes de medidas de un protocolo clínico para pacientes con sepsis grave y shock séptico y analizar su impacto sobre la supervivencia y la duración de estancias hospitalarias. Se incluyeron los datos de 125 pacientes divididos en grupo control $(\mathrm{N}=84)$ e intervención $(\mathrm{N}=41)$ de una Unidad de Cuidados Intensivos. El nivel de cumplimiento aumentó de $13,1 \%$ a $29,3 \%$ en 5 intervenciones del paquete de reanimación y de $14,3 \%$ a $22 \%$ en 3 intervenciones del paquete de seguimiento. La mortalidad hospitalaria a los 28 días disminuyó un $11,2 \%$ y la duración de la estancia hospitalaria se redujo en 5 días. Aunque el cumplimiento fue bajo, la intervención aumentó la adhesión a las indicaciones del protocolo clínico y se observó un descenso de la mortalidad a los 28 días y menor duración de estancias hospitalarias.
\end{abstract}

Descriptores: Efectividad; Protocolo Clínico; Sepsis; Cuidados Críticos.

\section{Introduction}

Severe sepsis represents a great challenge for health care. Considerable resources have been invested in research, as well as in the development of new treatments. Until the publication of the Guidelines for the Management of Severe Sepsis and Septic Shock by the International Sepsis Forum(1) in 2001, however, many aspects of care delivery to septic patients were not based on scientific evidence.

The publication of these guidelines served as the base to start the international campaign "Surviving Sepsis" in 2004(2), an international program designed for awareness-raising, planning and clinical guideline dissemination purposes. In 2005, after a program review, the so-called "Severe sepsis bundles"(3) are published, a range of activities and treatments designed for teams who attend to these patients to follow the times, sequences and objectives of individual components, with the final aim of reducing mortality due to severe sepsis by $25 \%$. There is great heterogeneity, however, in levels of compliance with these recommendations ${ }^{(4-5)}$. In this sense, clinical pathways, protocols seem to be proper instruments to plan and coordinate the sequence of medical, nursing and administrative procedures needed to achieve maximum efficiency in 
the care process ${ }^{(6-7)}$. The great quality improvement opportunities these instruments offer by standardizing care and establishing a multidisciplinary cooperation climate justified their rapid dissemination in the USA ${ }^{(8)}$ and explain the fact that, in most hospitals, they are used for the most frequent processes; that contrasts with the lack of implementation in Spain(9). As a result, we are interested in studying the management of the severe sepsis and septic shock process by comparing two models, the traditional and another based on the use of protocols and a clinical pathway developed based on the "Surviving Sepsis", with a view to assessing the degree of compliance with the intervention bundles proposed in the clinical protocol and analyze their impact on survival rates and on the duration of hospital stays.

\section{Methods}

\section{Sample, design and study context}

In this quasi-experimental study, developed at a general teaching hospital (HGU) in Spain, the application of a clinical pathway is analyzed by comparing a control group with an intervention group. The control group $(\mathrm{N}=84)$ included all adult patients, over 18 years of age, consecutively hospitalized at the Intensive Care Unit (ICU) between June 2008 and July 2009, coming from the Emergency Service, medical-surgical hospitalization wards or the emergency surgical services, who were diagnosed with severe sepsis or septic shock, according to the ICU discharge report. The intervention group $(\mathrm{N}=41)$ comprised all adult patients, over 18 years of age, who were hospitalized for treatment at the ICU with a confirmed diagnosis or considerable suspicion of severe sepsis or septic shock, coming from hospitalization wards, Urgency Services and/or emergency surgical service, between October 2009 and March 2010. The diagnosis or suspicion of severe sepsis or septic shock were based on the criteria of the American College of Chest Physicians/Society of Critical Care Medicine $(A C C P / S C C M)^{(10)}$.

Patients who had previously been treated for severe sepsis during more than 24 hours, younger than 18 , with trauma, convulsions, pulmonary edema due to heart failure, acute cerebrovascular accident, active hemorrhage, with an alternative diagnosis to explain the state of shock (e.g. acute myocardial infarction) and patients with orders not to reanimate or in extremely severe conditions, although the latter two groups were included if an aggressive medical treatment was used.

A clinical pathway was developed, based on the "Surviving Sepsis" campaign and adapted to the HGU context.
An education and training program was accomplished and reference guides were developed, made available at the nursing controls and on the sepsis web of the hospital intranet. Also, posters with protocol algorithms and diagrams were made and distributed across the different services involved.

The HGU management approved the study development and, as this was a quality improvement program, no Research Ethics Committee approval was necessary. The research itself did not add any risk to the treatment the patients receive and the application of a clinical pathway would but improve the prognosis. On the other hand, the use of clinical management tool is based on data collection and comparisons between two care models. Therefore, only the data necessary to accomplish this study were consulted. Information on the patients' identity was considered confidential for any and all purposes.

\section{Patient management}

A consensus existed on the definition of the diagnosis moment or "baseline" as the point when the criteria were met to start the specific intervention: 1) Two or more criteria of the Systemic Inflammatory Response Syndrome (SIRS): Tachycardia ( $\geq 90$ beats/ min), Tachypnea (>20 breaths/min) or Hypoxemia with SatO $_{2}<90 \%$ ), Hyperthermia of $\geq 38^{\circ}$ or hypothermia of $<35.5^{\circ} \mathrm{C}$ and white-cell count of $\geq 12000$ or $<4000$ cells/ $\mathrm{mm}^{3}$ or more than $10 \%$ of band neutrophils; 2 ) Suspected infection documented by radiological, clinical or surgical findings, presence of germs in normally sterile fluids or consistent clinical syndrome, with a high probability of infection; 3) Hypotension and/or hyperlactatemia and/or clinical and/or laboratory data suggesting the presence of at least one organ dysfunction.

Demographic and clinical characteristics were collected from all patients, including age, gender, origin of the sepsis, type of sepsis, Acute Physiology and Chronic Health Evaluation II Score (APACHE II), Sequential Organ Failure Assessment (SOFA), start place, organ dysfunctions, ICU entry and discharge date, Hospital discharge date.

After reaching the severe sepsis diagnosis, the application of the clinical pathways starts, divided in two phases: 1) six-hour reanimation phase and 2) 24-hour monitoring phase; each phase includes a bundle with different interventions. The sepsis groups in charge of developing the pathways elaborated both bundles. The reanimation bundle consists of seven interventions, focused on hemodynamic reanimation and early 
antimicrobial treatment, while the 24-hour monitoring treatment bundle includes four interventions.

Based on the variables related to the different treatment interventions, care and time intervals, quality criteria were constructed to reflect changes in daily practices and variability modifications (interventions made and interventions made within the preset time). The choice of the criteria was expected to comply with the following conditions: 1) Being based on a generally accepted clinical practice and supported by evidence. 2) Being adapted to the context where the clinical pathway is developed. 3) The achievement of each intervention can be determined by a "yes" or "no" in the clinical history review. Compliance indicators were constructed for the interventions in the six-hour reanimation bundle and the 24-hour monitoring bundle individually and as a whole. Also, a result indicator was constructed, measuring the effectiveness of compliance with the different interventions on 28-day mortality. The indicators were expected to comply with validity (identifying care quality) and specificity conditions (detecting only those cases in which the problem actually exists, no false positives) (Table 2 ).

\section{Data collection and analysis}

Clinical and demographic data for all patients were extracted from the Clinical Histories through two data collection forms, designed for this purpose in accordance with the Universidad de Loma Linda model(11) and the ARIAM model $v 1$ to register severe sepsis and septic shock $^{(12)}$.

The patients' characteristics were subject to descriptive analysis and differences between the control and intervention groups were compared (Student's T, Mann-Whitney's U and Chi-Square).

The standardized mortality rate was calculated as the ratio between observed mortality at 28 days and expected mortality (standardized by age and calculated in the ARIAM sepsis record based on the APACHE II score).

To determine the impact of the intervention and six and 24-hour bundles on the results, a multiple logistic regression model was created, which contained 28day mortality as the dependent variable. The following severity variables were introduced for adjustment purposes: APACHE II, SOFA, mechanical ventilation, infection origin, patient's origin according to the hospitalization ward or emergency service and age.

To analyze the association between mortality and each of the six and 24-hour intervention bundles, a logistic regression analysis was applied to each of the variables in these interventions. Moreover, the association between mortality and correct compliance was analyzed, considering at least four interventions in the six-hour bundle and none in the 24-hour bundle.

All analyses were developed using PASW Statistics version 18 and Epidat 3.1 software.

\section{Results}

\section{Clinical-epidemiological characteristics}

The incidence of severe sepsis/septic shock at the ICU of the HGU corresponded to 96 cases/year, which corresponds to a calculated accumulated incidence rate of $85 \pm 27$ cases of severe sepsis/septic shock per 100,00 inhabitants/year, a mean first-day SOFA score of 7.6 \pm 3.0 and APACHE II: $25.8 \pm 8.1$, and an expected mortality of $54.8 \pm 23.4$. At the moment of the diagnosis, the mean number of organs presenting dysfunctions was $3 \pm 1$ and failure of at least two organs was found in $21.9 \%$; the most frequent diagnosis was pneumonia (32.8\%).

In Table 1, it can be observed that patients in both groups were similar in terms of baseline epidemiological data, primary origin of the infection, severity at the moment of its presentation and expected mortality.

Table 1 - Comparison of clinical-epidemiological characteristics between control and intervention groups

\begin{tabular}{lccc}
\hline \multicolumn{1}{c}{ Variables } & $\begin{array}{c}\text { Control } \\
\mathbf{N}=\mathbf{8 4}\end{array}$ & $\begin{array}{c}\text { Intervention } \\
\mathbf{N}=\mathbf{4 1}\end{array}$ & P-value \\
\hline Age, years (mean \pm SD) & $64.7 \pm 12.3$ & $63.3 \pm 14.1$ & 0.6 \\
Boys, $\mathrm{n}(\%)$ & $46(54.8)$ & $26(63.4)$ & 0.5 \\
Girls, $\mathrm{n}(\%)$ & $38(45.2)$ & $15(36.6)$ & 0.5 \\
Severity Indicators & & & \\
APACHE II (mean \pm SD) & $26.3 \pm 8.2$ & $24.9 \pm 7.8$ & 0.4 \\
SOFA (mean \pm SD) & $7.7 \pm 2.8$ & $7.5 \pm 3.5$ & 0.7 \\
Mechanical ventilation. $\mathrm{n}(\%)$ & $62(73.8 \%)$ & $29(70.7 \%)$ & 0.9 \\
Lactate (mean \pm SD) & $4.56 \pm 3.8$ & $4.21 \pm 2.6$ & 0.6
\end{tabular}


Table 1 - (continuation)

\begin{tabular}{|c|c|c|c|}
\hline Variables & $\begin{array}{c}\text { Control } \\
N=84\end{array}$ & $\begin{array}{l}\text { Intervention } \\
\mathrm{N}=41\end{array}$ & P-value \\
\hline Expected mortality (mean $\pm S D$ ) & $56.2 \pm 23.5$ & $52.2 \pm 23.1$ & 0.4 \\
\hline \multicolumn{4}{|l|}{ Infection Origin (n, \%) } \\
\hline Pneumonia & $31(39.7)$ & $10(34.5)$ & 0.7 \\
\hline Intra-abdominal infection & $16(20.5)$ & $5(17.2)$ & 0.9 \\
\hline Cholecystitis/Cholangitis & $5(6.4)$ & $3(10.3)$ & 0.8 \\
\hline Urinary tract infection & $15(19.2)$ & $4(13.8)$ & 0.7 \\
\hline Soft-tissue infection & $6(7.7)$ & $1(3.4)$ & 0.7 \\
\hline Implantable devices & 0 & $3(10.3)$ & 0.03 \\
\hline Meningitis & $2(2.6)$ & $1(3.4)$ & 0.7 \\
\hline Others & $3(3.8)$ & $2(6.9)$ & 0.9 \\
\hline \multicolumn{4}{|l|}{ Type of sepsis at baseline $(n, \%)$} \\
\hline Severe sepsis & $28(29.7)$ & $17(41.6)$ & 0.5 \\
\hline Septic shock & $66(70.2)$ & $24(58.5)$ & 0.03 \\
\hline Medical sepsis & $57(67.8)$ & $26(63.4)$ & 0.8 \\
\hline Surgical sepsis & $27(32.1)$ & $15(36.6)$ & 0.8 \\
\hline \multicolumn{4}{|l|}{ Origin before ICU admission (n, \%) } \\
\hline Urgencies & $59(70.2)$ & $31(75.6)$ & 0.7 \\
\hline Ward & $25(29.8)$ & $10(24.4)$ & 0.7 \\
\hline \multicolumn{4}{|l|}{ Organ failure at baseline $(n, \%)$} \\
\hline \multicolumn{4}{|l|}{ No. organs } \\
\hline 1 & $2(2.4)$ & $1(2.4)$ & 0,5 \\
\hline 2 & $20(23.8)$ & $9(21.9)$ & 0,9 \\
\hline 3 & $25(29.7)$ & $12(29.2)$ & 0,9 \\
\hline 4 & $27(32.1)$ & $11(26.8)$ & 0,7 \\
\hline$\geq 5$ & $10(11.9)$ & $8(19.5)$ & 0,4 \\
\hline \multicolumn{4}{|l|}{ Type of organ failure $(n, \%)$} \\
\hline Hemodynamic & $80(95.2)$ & $38(92.7)$ & 0.9 \\
\hline Respiratory & $51(60.7)$ & $22(53.6)$ & 0.6 \\
\hline Renal & $63(75)$ & $30(73.2)$ & 0.9 \\
\hline Liver & $3(3.6)$ & $6(14.6)$ & 0.1 \\
\hline Coagulation & $28(33.3)$ & $18(43.9)$ & 0.4 \\
\hline Thrombocytopenia & $23(27.4)$ & $13(31.7)$ & 0.8 \\
\hline Neurologic & $34(40.4)$ & $11(26.8)$ & 0.2 \\
\hline
\end{tabular}

Table 2 displays the univariate analysis of compliance with the different intervention bundles proposed in the clinical pathway. At six hours, the control group showed lower adherence levels to interventions 2, 4, 5 and 6 in comparison with the intervention group. The same happens at $24 \mathrm{~h}$ for interventions 3 and 4 of the monitoring bundle. None of the patients completed the seven interventions of the reanimation bundles within the established time. Only 33 (26.4\%) patients in both groups complied with at least five interventions in the six-hour package $(13.1 \%$ in the control group vs. $29.3 \%$ in the intervention group, $p<0.05)$. This number dropped to eight $(6.5 \%)$ when considering at least six interventions (1.2\% vs. $17 \%$ in the two groups, respectively).

Table 2 - Level of compliance with the interventions in the six-hour and 24-hour intervention bundles proposed in the clinical pathway

\begin{tabular}{|c|c|c|c|c|}
\hline Six-hour bundle & $\begin{array}{l}\text { Total } \\
\text { n (\%) }\end{array}$ & $\begin{array}{l}\text { Control } \\
\mathrm{n}(\%)\end{array}$ & $\begin{array}{l}\text { Intervention } \\
\mathrm{n}(\%)\end{array}$ & P-value \\
\hline \multicolumn{5}{|l|}{ 1. Serum lactate measure } \\
\hline $\begin{array}{l}\text { (Percentage of patients with severe sepsis or septic shock whose blood lactate level } \\
\text { was measured within } \pm 2 \text { hours from the diagnosis)* }\end{array}$ & $85(64)$ & $55(64.7)$ & $30(60.0)$ & 0.6 \\
\hline \multicolumn{5}{|l|}{ 2. Blood culture before antibiotics } \\
\hline (Percentage of patients with severe sepsis or septic shock for whom blood cultures & $73(58.4)$ & $44(52.4)$ & $29(70.7)$ & 0.04 \\
\hline
\end{tabular}

were obtained before the administration of broad-spectrum antibiotics) 
Table 2 - (continuation)

\begin{tabular}{|c|c|c|c|c|}
\hline Six-hour bundle & $\begin{array}{l}\text { Total } \\
\text { n (\%) }\end{array}$ & $\begin{array}{c}\text { Control } \\
\mathrm{n}(\%)\end{array}$ & $\begin{array}{l}\text { Intervention } \\
\text { n (\%) }\end{array}$ & P-value \\
\hline \multicolumn{5}{|l|}{ 3. Early antibiotics administration (120 min) } \\
\hline $\begin{array}{l}\text { (Percentage of patients with severe sepsis or septic shock who received broad- } \\
\text { spectrum antibiotics during the first } 60 \text { minutes after the diagnosis) }\end{array}$ & $50(40.9)$ & $33(40.7)$ & $17(41.5)$ & 0.9 \\
\hline \multicolumn{5}{|l|}{ 4. Initial volume administration ( $>20 \mathrm{~mL} / \mathrm{Kg}$ during the first two hours) } \\
\hline $\begin{array}{l}\text { (Percentage of patients with severe sepsis or septic shock and hypotension or } \\
\text { lactate level }>4 \mathrm{mmol} / \mathrm{l} \text { who initially received } 20 \mathrm{~mL} / \mathrm{Kg} \text { within less than two hours) }\end{array}$ & $67(53.6)$ & $35(41.7)$ & $32(78)$ & $<0.001$ \\
\hline \multicolumn{5}{|l|}{ 5. Achieve $\mathrm{CBP}>8 \mathrm{mmHg}$} \\
\hline $\begin{array}{l}\text { Percentage of patients with severe sepsis or septic shock for whom CBP }>8 \mathrm{mmHg} \\
\text { was achieved within six hours after the identification of septic shock or lactate level > } \\
4 \mathrm{mmol} / /[36 \mathrm{mg} / \mathrm{dll}] \text { ) }\end{array}$ & $38(69.6)$ & $16(19)$ & $22(53.6)$ & $<0.01$ \\
\hline \multicolumn{5}{|l|}{ 6. Achieve Central Venous Oxygen Saturation $>70 \%$} \\
\hline $\begin{array}{l}\text { (Percentage of patients after the identification of septic shock or lactate levels }>4 \\
\mathrm{mmol} / /(36 \mathrm{mg} / \mathrm{dl}) \text { for whom } \mathrm{ScvO}_{2} \text { is }>70 \% \text { within six hours after the diagnosis) }\end{array}$ & $19(30.4)$ & $11(13.1)$ & $18(43.9)$ & $<0.01$ \\
\hline \multicolumn{5}{|l|}{ 7. Blood pressure $\geq 90 \mathrm{mmHg}$ in case of hypotension } \\
\hline $\begin{array}{l}\text { (Percentage of patients who. in case of hypotension. achieve and maintain a MBP } \geq \\
65 \mathrm{mmHg} \text { or SBP } \geq 90 \mathrm{mmHg} \text { within six hours subsequent to the hypotension) }\end{array}$ & $92(73.6)$ & $60(71.4)$ & $32(78)$ & 0.4 \\
\hline 24-hour bundle & $\begin{array}{l}\text { Total } \\
\text { n (\%) }\end{array}$ & $\begin{array}{c}\text { Control } \\
\text { n (\%) }\end{array}$ & $\begin{array}{l}\text { Intervention } \\
\text { n (\%) }\end{array}$ & P-value \\
\hline \multicolumn{5}{|l|}{ 1. Corticoid administration ${ }^{\dagger}$} \\
\hline $\begin{array}{l}\text { (Percentage of patients with septic shock and refractory hypotension who were } \\
\text { administered low doses of corticoids according to the standard ICU policy within } 24 \\
\text { hours after the presentation) }\end{array}$ & $42(33.6)$ & $26(30.5)$ & $16(40.0)$ & 0.3 \\
\hline \multicolumn{5}{|l|}{ 2. Glucose $e^{\ddagger}>120$ and $<180 \mathrm{mg} / \mathrm{dL}$} \\
\hline $\begin{array}{l}\text { (Percentage of patients with severe sepsis or septic shock whose serum glucose } \\
\text { level was maintained at } 120-180 \mathrm{mg} / \mathrm{dL} \text { during the first } 24 \text { hours) }\end{array}$ & $61(54.5)$ & $39(51.3)$ & $22(61.1)$ & 0.4 \\
\hline \multicolumn{5}{|l|}{ 3. Activated protein $\mathrm{C}$ administration $\$$} \\
\hline $\begin{array}{l}\text { (Percentage of patients with septic shock who were administered activated } C \text { protein } \\
\text { according to the standard ICU policy within the first } 24 \text { hours after the presentation) }\end{array}$ & $48(34.4)$ & $16(19.0)$ & $32(80.0)$ & $<0.01$ \\
\hline \multicolumn{5}{|l|}{ 4. Plateau pressure $<30 \mathrm{~cm} \mathrm{H}_{2} \mathrm{O}$} \\
\hline $\begin{array}{l}\text { (Percentage of patients who needed mechanical ventilation and have a mean } \\
\text { inspiratory plateau pressure }<30 \mathrm{~cm} \mathrm{H}_{2} \mathrm{O} \text { during the first } 24 \text { hours after presenting } \\
\text { severe sepsis or septic shock [the median of all measures is obtained]) }\end{array}$ & $25(30.1)$ & $6(10.3)$ & $19(82.6)$ & $<0.01$ \\
\hline
\end{tabular}

When considering both groups, adherence to antibiotics administration in the first $120 \mathrm{~min}$. was achieved in $40.9 \%$ of the patients. The intervention did not change compliance rates ( $40.7 \%$ vs. $41.5 \%$, $p=0.9)$. When the cut-off point for antibiotics administration is limited to the first 60 minutes after the diagnosis (31.1\% of patients), mortality rates among these patients $(26.3 \%)$ are lower when compared with patients who receive antibiotics after more than three (50\%) or more than six hours (70\%), evidencing how delayed antibiotics administration decreases survival rates (Figure 1 ).

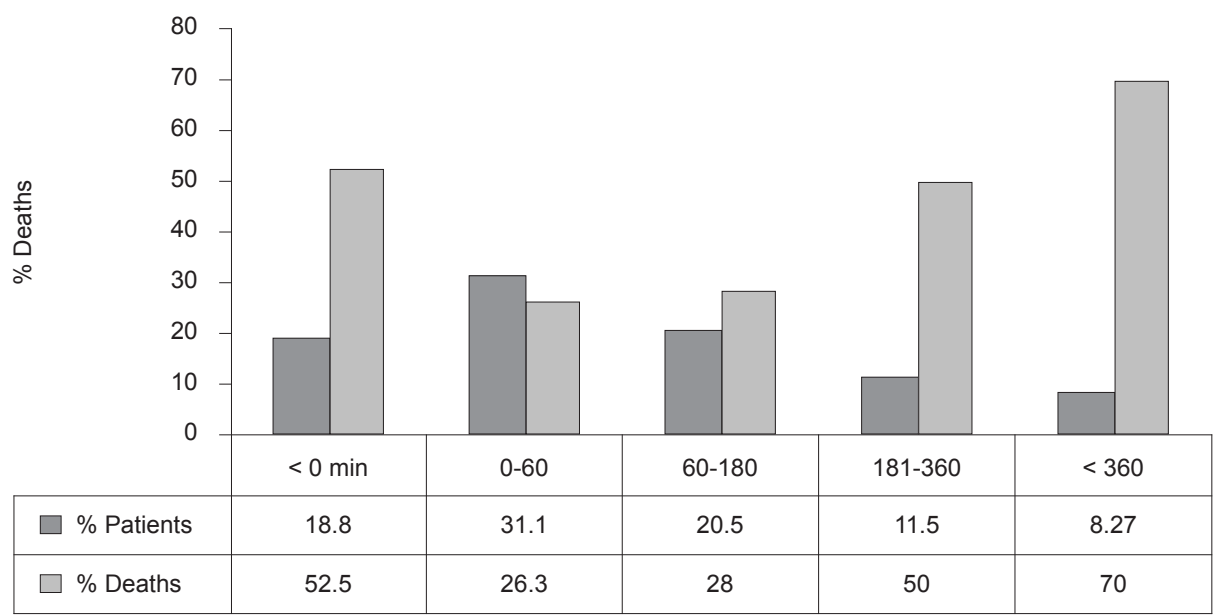

Figure 1 - Antibiotics administration delay and mortality 
Mortality rates at 28 days were lower among intervention group patients $(31.7 \%)$ when compared with control group patients $(42.9 \%)$, with a difference of $11.2 \%(p=0.2)$. Hospital mortality and ICU mortality rates were similar in both groups: in the first case $40.4 \%$ in the control group and $39.9 \%$ in the intervention group and, in the second, $32.1 \%$ and $29.3 \%$, respectively. The standardized mortality rate dropped from 0.76 (95\% CI, 0.68-0.87) in the historical group to 0.60 (95\% CI, 0.470.82 ) in the intervention group, although this difference was not significant.

Effectiveness was analyzed among patients who had complied with $\geq 4$ and $\geq 5$ interventions in the reanimation bundle. The OR adjusted by the severity indicators: APACHE II, SOFA, mechanical ventilation, origin of the infection, origin of the patient (ward or emergency) and age corresponded to $\mathrm{OR}=0.87$ $(0.35-2.13) \mathrm{p}$ value $=0.8$ and $\mathrm{OR}=0.65(0.29-2.17)$, respectively. As for the 24-hour monitoring bundle, at least three interventions were complied with in only $16.8 \%$ of cases, although compliance with at least three interventions improved in the intervention group, from 14.3 to $22 \%$. Figure 2 graphically represents the probability of death among patients who received the six-hour and 24-hour intervention bundle, respectively, within the correct time. Patients who had not received these interventions or beyond the time margins set in the pathway were considered as a reference. The graph reveals a trend towards lower death risk in compliance with the six-hour reanimation bundle; this is not the case for the 24-hour monitoring bundle though.

\begin{tabular}{|c|c|c|c|c|c|}
\hline & OR & IC 95\% & & & \\
\hline \multicolumn{6}{|l|}{ 6-hour reanimation bundle } \\
\hline Lactate measure & 0.8 & $(0.2,3.1)$ & & & 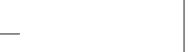 \\
\hline Hemoculture & 2.4 & $(0.9,6.3)$ & & & \\
\hline Early antibiotics treatment & 0.7 & $(0.3,1.9)$ & & - & \\
\hline In case of hypotension, intravenous fluid administration & 0.2 & $(0.0,2.1)$ & & - & \\
\hline Reach $\mathrm{SBP}>90 \mathrm{mmHg}$ or $\mathrm{MBP}>65 \mathrm{mmHg}$ & 0.4 & $(0.2,0.9)$ & & & \\
\hline Central venous pressure $>8 \mathrm{mmHg}$ & 0.3 & $(0.1,1.6)$ & & 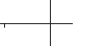 & \\
\hline Central venous oxygen saturation $>70$ & 0.5 & $(0.1,2.1)$ & & - & \\
\hline \multicolumn{6}{|l|}{ 24-hour monitoring bundle } \\
\hline Steroid administration & 2 & $(0.9,4.3)$ & & - & \\
\hline Glucose $150-180 \mathrm{mg} / \mathrm{dl}$ & 1.1 & $(0.4,3.1)$ & & 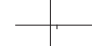 & - \\
\hline Glucose $<150$ & 0.9 & $(0.4,2.1)$ & & $\longrightarrow$ & \\
\hline Activated $\mathrm{C}$ protein administration & 1.9 & $(0.8,4.5)$ & & & \\
\hline \multirow[t]{2}{*}{ Plateau pressure $<30 \mathrm{~cm} \mathrm{H}_{2} \mathrm{O}$} & 2 & $(0.5,8.6)$ & & & \\
\hline & & & $<$ Prob. Death & $\mathrm{OR}=1$ & > Prob. Death \\
\hline
\end{tabular}

CI: Confidence Interval; OR: Odds Ratio

Figure 2 - Representation of death probability in patients who received intervention in the correct period (in relation to patients who did not or beyond the times established in the clinical pathway)

The mean duration of hospitalization for intervention group patients, calculated as from the diagnosis (baseline), dropped by five days, from 23.3 (4-11) days in the historical group to 17.6 (12.7-32) in the intervention group, and the duration of the ICU stay also dropped from $8.6 \pm 11.9$ to $7.1 \pm 6.4$.

\section{Discussion}

The study showed that the incidence rate of severe sepsis in the study context was in line with descriptions in Spanish epidemiological studies, with high lethality levels, prolonged hospital stays and high prevalence rates of multiple organ failure at the time of the diagnosis. Severe sepsis entails high lethality rates in the first 48 hours, which suggests delays in the diagnosis, reanimation and establishment of antibiotics therapy. Results from earlier studies range from a mild trend towards improved survival(13) to a significant drop in mortality rates ${ }^{(14-16)}$. These studies differ from the present in that most were accomplished at Emergency Services and include many patients with severe sepsis, who usually demand less aggressive reanimation and show lower mortality rates than patients in septic shock. 
In our series, the protocol was predominantly developed at the ICU, were patients are in more severe conditions and at a high risk of developing nosocomial infections, which contribute to aggravate their condition(17).

Concerning adherence to different interventions, all results improved after the education program, similar to other research results ${ }^{(4,18)}$ and lower than in other investigations ${ }^{(14,19)}$, although the latter considered less interventions.

The intervention did not change adherence to antibiotics administration within the first 120 minutes. This is probably due to the fact that baseline figures are relatively high. Our data show, however, how mortality rises when antibiotics administration is delayed. A study showed that, for each hour of delay in antibiotics administration, mortality increases by $7.6 \%{ }^{(20)}$. When comparing the intervention group with the control group, the decreased mortality seems to be due to the lower number of patients who receive antibiotics treatment after six hours, as well as to the drop in mortality rates among patients who receive this medication in the first hour. Thus, considering the low compliance levels with Early Goal-Directed Treatment (EGDT), improved antibiotics administration could better explain the lower mortality rate detected in our series than the rest of the interventions. The findings are consistent with another study(21), and the recommendations of the "surviving sepsis" campaign that emphasize appropriate antibiotics administration is one of the interventions in the six-hour reanimation protocol that should be done, if possible, in the first hour after the diagnosis.

Recently, the results of data accumulated between 2005 and 2008 have been published, considering 15,022 patients from 165 centers who actively participated in the monitoring of the "surviving sepsis" campaign(19). The conclusions were that adherence to compliance with the pathways increased over time, so that, at the end of two years of campaign, adherence to the six-hour reanimation bundle" rose linearly from $10.9 \%$ to $31.3 \%$, while adherence with the "24-hour monitoring protocol" rose from $18.4 \%$ to $36.1 \%$. Non-adjusted mortality dropped from $37 \%$ to $30.8 \%$ after two years.

As observed, although increased adherence tends to be statistically significant in large series, rates continue relatively low.

Compliance with individual components is much higher, on the other hand. Although the defense of the "bundles" is based on the fact that they are more effective if administered as a whole, some experts appoint that it may not be strictly necessary to complete all interventions to gain benefits, although survival rates do improve significantly with the number of interventions received. In another study, achieving more than four interventions from the six-hour reanimation bundle (no matter which) was associated with a lower death risk. The highest probability was obtained with six or more interventions but, when they were removed from the regression model one by one, the rest of the "bundle" maintained its protective effect, with statistical significance ${ }^{(18)}$.

Regarding the benefits of applying the "24-hour bundle", disagreements exist in the interpretation of trials. Various researchers have reported decreased death risks among compliers with the "bundle" in comparison with non-compliers ${ }^{(15,18)}$. Our results did not show a drop in mortality risks in any of the interventions. The results of a recently published meta-analysis showed higher survival rates with the six-hour than with the 24-hour bundle(22).

\section{Conclusion}

The intervention was associated with greater adherence to the clinical pathway, although compliance levels remained low. After the intervention, a trend towards improved survival rates was observed, with lower $28^{\text {th }}$-day mortality rates and shorter hospital stays. The main study limitations are related to the sample size and selection form. Our results are significant though, and contribute to knowledge on sepsis management in clinical practice, showing that standardization, organization and local consensus are key quality components, suggesting that the clinical pathway can be a principle to put in practice the planning and continuous improvement of a highly complex care process.

\section{References}

1. Sprung ChL, Bernard GR, Dellinger P; International Sepsis Forum. Guidelines for the management of severe sepsis and septic shock. Intensive Care Med. 2001;27 Suppl 1:S1-134.

2. Dellinger RP, Carlet JM, Masur H, Gerlach H, Calandra T, Cohen J, et al. Surviving Sepsis Campaign guidelines for management of severe sepsis and septic shock. Crit Care Med. 2004;32(3):858-73.

3. Institute for Healthcare Improvement (Internet). Severe Sepsis Bundles. 2005. [acesso 15 set 2011]. Disponível em: http://www.ihi.org/IHI/Topics/ CriticalCare/Sepsis/Tools/SevereSepsisBundle.htm. 
4. Ferrer R, Artigas A, Levy MM, Blanco J, González-Díaz G, Garnacho-Montero J, et al. Improvement in process of care and outcome after a multicenter severe sepsis educational program Spain. JAMA. 2008;299(19):2294-303.

5. Stoneking $L$, Denninghoff $K$, Deluca L, Keim SM, Munger B. Sepsis bundles and compliance with clinical guidelines. J Intensive Care Med. 2011;26(3):172-82.

6. Campbell $\mathrm{H}$, Hotchkiss $\mathrm{R}$, Bradshaw N, Porteous $M$. Integrated care pathways. BMJ. 1998;316:133-7.

7. Rotter T, Kinsman L, James E, Machotta A, Gothe $\mathrm{H}$, Willis $\mathrm{J}$, et al. Clinical pathways: effects on professional practice, patient outcomes, length of stay and hospital costs. Cochrane Database Syst Rev. 2010;17(3): CD006632.

8. Saint S, Hofer TP, Rose JS, Kaufman SR, McMahon LF Jr. Use of critical pathways to improve efficiency: a cautionary tale. Am J Manag Care. 2003;9(11):758-65.

9. Carraco G, Ferrer J. Las vías clínicas basadas en la evidencia como estrategia para la mejora de la calidad: metodología, ventajas y limitaciones. Rev Calidad Asistencial. 2001;16:199-207.

10. American College of Chest Physicians/Society of Critical Care Medicine Consensus Conference: definitions for sepsis and organ failure and guidelines for the use of innovative therapies in sepsis. Crit Care Med. 1992;20(6):864-74.

11. Nguyen HB, Rivers EP, Abrahamian FM, Moran GJ, Abraham E, Trzeciak S, et al. Severe sepsis and septic shock: review of the literature and emergency department management guidelines. Ann Emerg Med. 2006;48(1):28-54.

12. ARIAM-Andalucía [Internet]. Disponível em:

http://www.paisepsiscalidad.org/Login.aspx?ReturnUrl =\%2fsepsis $\% 2$ fFrameSet.aspx

13. Shapiro NI, Howell MD, Talmor D, Lahey D, Ngo $\mathrm{L}$, Buras J, et al. Implementation and outcomes of the Multiple Urgent Sepsis Therapies (MUST) protocol. Crit Care Med. 2006;34(4):1025-32.

14. Nguyen HB, Corbett SW, Steele R, Banta J, Clark RT, Hayes SR, et al. Implementation of a bundle of quality indicators for the early management of severe sepsis and septic shock is associated with decreased mortality. Crit Care Med. 2007;35(4):1105-1.

15. Gao F, Melody T, Daniels DF, Giles S, Fox S. The impact of compliance with 6-hour and 24-hour sepsis bundles on hospital mortality in patients with severe sepsis: a prospective observational study. Crit Care. 2005;9(6):R764-70.
16. El Solh AA, Akinnusi ME, Alsawalga LN, Pineda LA. Outcome of septic shock in older adults after implementation of the sepsis "bundle". J Am Geriatr Soc. 2008;56(2):272-8.

17. de Oliveira AC, Kovner CT, da Silva RS. Nosocomial infection in an intensive care unit in a Brazilian university hospital. Rev. Latino-Am. Enfermagem. 2010;18(2):233-9.

18. Castellanos-Ortega A, Suberviola B, García-Astudillo LA, Holanda MS, Ortíz F, Llorca J, et al. Impact of the Surviving Sepsis Campaign protocols on hospital length of stay and mortality in septic shock patients: results of a three-year follow-up quasi-experimental study. Crit Care Med. 2010;38(4):1036-43.

19. Levy MM, Dellinger RP, Townsed SR, Linde-Zwirble WT, Marshal JC, Bion J, et al. The Surviving Sepsis Campaign: results of an international guideline-based performance improvement program targeting severe sepsis. Intensive Care Med. 2010;36(2):222-31.

20. Kumar A, Roberts D, Wood KE, Light B, Parrillo JE, Sharma S, et al. Duration of hypotension before initiation of effective antimicrobial therapy is the critical determinant of survival in human septic shock. Crit Care Med. 2006;34(6):1589-96.

21. Gaieski DF, Mikkelsen ME, Band RA, Pines JM, Massone R, Furia FF, et al. Impact of time to antibiotics on survival in patients with severe sepsis or septic shock in whom early goal-directed therapy was initiated in the emergency department. Cri Care Med. 2010;38(4):1045-53.

22. Chamberlain DJ, Willis EM, Bersten AB. The severe sepsis bundles as processes of care: A meta-analysis. Aust Crit Care. 2011;24(4). 